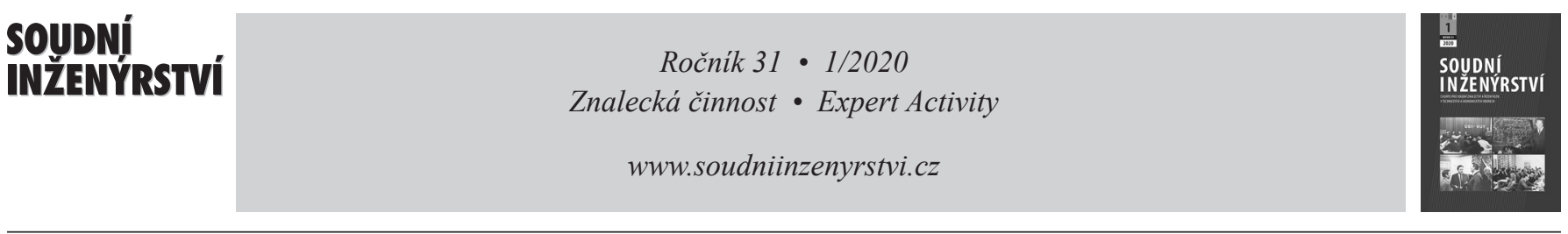

\title{
Aktuální stav rekodifikace veřejného stavebního práva
}

\author{
Recent Status of Public Construction Law Recodification
}

\author{
Alena Kliková* \\ Masarykova univerzita, Právnická fakulta
}

\begin{abstract}
Abstrakt
Příspěvek je věnován otázkám spojeným se změnami a legislativním vývojem právní úpravy veřejného stavebního práva, a to ve vztahu k praktickým dopadům těchto změn. Stavební zákon v posledních letech neustále prochází změnami, které mají vést ke zrychlení a zjednodušení jednotlivých procesů vedoucích $\mathrm{k}$ povolování staveb. V současné době probíhá rozsáhlá rekodifikace nejenom stavebního zákona, ale veřejného práva jako celku, včetně reorganizace veřejné správy. Př́ispěvek bude zaměřen na současný stav rekodifikace, včetně vybraných plánovaných změn. Př́íspěvek prezentován a publikován na konferenci ExFoS 2020.
\end{abstract}

Klícová slova: stavební zákon, územní plánování, stavební povolení, kolaudace, užívání staveb.

\section{1. ÚVOD}

Veřejné stavební právo lze považovat za oblast práva, která je nejenom velmi prakticky a odborně zaměřená, ale je to i oblast, která je legislativně zakotvována již po desítky let. Jak bylo mnohokrát uvedeno, pravidla pro výstavbu byla na území zemí českých kodifikována již v době středověku, a to nejenom jako pravidla pro výstavbu, ale byly zakotvovány i technické podmínky výstavby a kontroly splnění těchto podmínek ze strany vrchnosti. Podrobná právní úprava byla zakotvena v 19. století. Právní zakotvení veřejného stavebního práva z konce 19. století lze považovat za kvalitní, a to i s ohledem na to, že př́islušné zákony platily do konce čtyřicátých let 20. století. Po této etapě dochází ke změnám $\mathrm{v}$ legislativě $\mathrm{v}$ návaznosti na změny ve společnosti. V roce 2006 je schválen a vydán stavební zákon č. 183/2006 Sb., který nabyl účinnosti k 1. 1.2007. Tento stavební zákon byl za svoji krátkou dobu účinnosti již mnohokrát novelizován. Jak bylo v řadě prrípadů uváděno zákonodárci, některé tyto novely byly tzv. zásadní. Poslední velká novela byla schválena v roce 2017 (zákon

\begin{abstract}
The paper deals with the issues related to the changes and the legislative development of the legal regulation of the Building Act, in relation to the practical effects of these changes. The Building Act has been constantly undergoing changes in recent years to lead to the acceleration and simplification of individual construction permitting processes. At present, extensive recodification is under way not only of the Building Act, but of public law as a whole, including the reorganization of public administration. The paper will focus on the current state of recodification, including selected planned changes.
\end{abstract}

Keywords: building act, territorial planning, building permits, acceptance, use of buildings.

č. 225/2017 Sb.) s účinností od 1. 1. 2018. Avšak ani tato legislativní změna nepřinesla očekávané výsledky a nedosáhla kýženého cíle. Jako zásadní problém stávajícího legislativního prostředí ve vztahu k povolování staveb bývá uváděna pomalost jednotlivých rrizení, konkrétně délka procesu vedoucího k povolení staveb. Jedná se o opakovaně kritizovaný problém české právní úpravy veřejného stavebního práva.

V současné době je legislativně projednávána komplexní rekodifikace celého veřejného stavebního práva, která se dotkne nejenom stavebního zákona, ale obrovského množství právních předpisů, které se stavebnictvím souvisí. Deklarovaným cílem zákonodárce je snaha přiblížit veřejné stavební právo standardům vedoucím k jeho zefektivnění, odstranění obstrukcí, průtahů či bariér, které dnes omezují výstavbu a rozvoj České republiky. Jak bylo uvedeno v úvodu vymezených cílü1), dnešní společenské a ekonomické prostředí si žádá, aby stavební právo stanovilo jednoduchá, aplikovatelná, vymahatelná a srozumitelná pravidla,

1) Viz www.mmr.cz. 
která zajistí výstavbu klíčových dopravních staveb a další infrastruktury.

Příspěvek se níže bude věnovat aktuálnímu stavu výše uvedené rekodifikace a vybraným navrhovaným změnám.

\section{AKTUÁLNÍ STAV REKODIFIKACE ${ }^{2)}$}

\subsection{Věcný záměr stavebního zákona}

V roce 2019 byl zveřejněn věcný záměr stavebního zákona, který představil základní pravidla veřejného stavebního práva, včetně návrhu na reformu veřejné správy, která by měla být součástí rekodifikace veřejného stavebního práva.

Dle článku 4. Legislativních pravidel vlády, věcný záměr obsahuje mimo jiné návrh věcného řešení, z něhož musí být zřejmé, že:

1. navrhované řešení navazuje na provedené zhodnocení,

2. z vyhodnoceni alternativnich řšsení, která byla při př́pravě věcného záměru zvažována, a z vyhodnoceni důsledků neprijetí navrženého řěseni vyplývá, že věc nelze rešit jinak než zákonnou úpravou.

Dále věcný záměr návrhu zákona obsahuje také zpưsob promitnutí navrhovaného věcného řě̌eni do právního ř́du, préedpokládaný hospodárský a finančni dosah navrhované právni úpravy na státni rozpočet, ostatni veřejné rozpočty, na podnikatelské prostředi České republiky, dále sociálni dopady, včetně dopadi̊ na specifické skupiny obyvatel, zejména osoby sociálně slabé, osoby se zdravotním postižením a národnostni menšiny, a dopady na životni prostředi.

V únoru (6.2.2019) byl věcný záměr stavebního zákona předán k připomínkovému řízení, které bylo ukončeno 28. 2. 2019. Věcný záměr následně projednali komise Legislativní rady vlády a dne 19. 6. 2019 k návrhu vydala stanovisko předsedkyně Legislativní rady vlády ${ }^{3)}$.

\subsection{Paragrafované znění stavebního zákona}

Paragrafované znění nového stavebního zákona bylo předloženo $\mathrm{k}$ připomínkovému rrízení dne 25. 11. 2019. Připomínkové řízení bylo ukončeno dne 23. 12. 2019.

V současné době navržené paragrafované znění stavebního zákona by mělo projít fází vypořádání připomínek. Dále dle článku 10 Legislativních pravidel návrh zákona, upravený podle výsledkü pripomínkového rízení, poprípadě i podle připomínek nebo podrobných stanovisek Evropské komise nebo jiných členských států Evropské unie v prípadě podle čl. 2a, nebo podle výsledku konzultace v prípadě podle čl. 8 a, se zašle k projednání vládě tak, že se po souhlasu osoby, která stojí v čele orgánu, který návrh zákona zpracoval, nejprve vloži do elektronické knihovny a v týž den zašle člen vlády návrh zákona předsedovi vlády. Vložení návrhu zákona do elektronické knihovny Úřadu vlády se považuje rovněž za předložení návrhu zákona Legislativni radě, která je povinna návrh projednat ve lhưtě do 60 dnů. Před samotným posouzením

\footnotetext{
2) Př́íspěvek byl zpracován dle stavu rekodifikace ke dni 13. 1. 2020, s tím, že stav rekodifikace se průběžně doplňuje v návaznosti na aktuální projednávání a pokračování legislativního procesu.

3) https://www.mmr.cz/getattachment/a948d179-a4a3-4229-912cf3a9a7086552/predsedkyne-LRV-final.pdf.aspx?lang=cs-CZ\&ext=.pdf (zdroj ke dni 13. 1. 2020).
}

Legislativní radou bývá návrh zákona předložen vybraným komisím Legislativní rady vlády.

Dle článku 11 Legislativních pravidel návrh zákona, schválený vládou ve zněni upraveném podle závěrů ze schi̊ze vlády, je vládním návrhem zákona. Součástí vládního návrhu zákona je důvodová zpráva. Orgán, který návrh zákona vládě předložil, vloži vládní návrh zákona, včetně důvodové zprávy a dalšich souvisejicich materiálů zasílaných s vládním návrhem zákona Poslanecké sněmovně, do elektronické knihovny.

\section{VYBRANÉ NAVRHOVANÉ ZMĚNY}

\subsection{Reorganizace veřejné správy a dotčené orgány}

Jak je uváděno Ministerstvem pro místní rozvoj, rekodifikace by měla z institucionálního hlediska zajistit vybudování nové dvoučlánkové soustavy stavebních úřadů tvořené Nejvyšším stavebním úřadem a krajskými stavebními úřady se sídlem v jednotlivých krajích s územními pracovišti v obcích s rozšířenou působnostíi). Vytvoření jednotné struktury státní stavební správy je považováno předkladatelem za zásadní změnu, která odstraní nedostatky v činnosti stavebních úřadů a dotčených orgánů. Nejvyšší stavební úřad bude ústředním správním úřadem s celostátní působností. Oddělením státní správy od samosprávy zcela zmizí i hrozba systémové podjatosti, která plyne právě ze spojeného modelu veřejné správy a je dnes velkým problémem ${ }^{5}$.

Mělo by také dojít k částečné integraci dotčených orgánů do státní stavební správy. Mělo by dojít k přesunu některých pravomocí $\mathrm{z}$ dosavadních dotčených orgánů. Jejich kompetence a činnosti by měly být integrované v nově vzniklém stavebním úřadu. Konkrétně $\S 4$ navrhovaného stavebního zákona uvádí:

„Ochrana veřejných zájmi̊

Státni stavebni správa chráni veřejné zájmy podle tohoto zákona a dalši veřejné zájmy zejména v oblasti

a) života a zdraví lidí,

b) životního prostředí a přirodnich zdrojů,

c) státni památkové péče,

d) veřejné infrastruktury,

e) půdního fondu, zemédělství, lesnictví a chovatelství,

f) nerostného bohatství, hornické činnosti a výbušnin,

g) výroby a hospodařeni s energii,

h) obrany a bezpečnosti státu,

i) požárni ochranya integrovaného záchranného systému,

j) prevence závažných havárii, integrované prevence a omezováni znečištěni,

k) práva na územní samosprávu. “

Dotčené orgány by většinou neměly vydávat samostatná podkladová stanoviska pro rozhodnutí, ale měly by se přímo podílet

\footnotetext{
4) Pozn.: V návaznosti na projednávání připravované novelizace došlo ke změnám, a to $\mathrm{k}$ návrhu, aby na úrovni obcí s rozšířenou působností zůstal současný spojený model veřejný správy zachován a výkon stavebního úřadu byl zajištěn v přenesené působnosti. Zdroj: https://www.mmr.cz/ getmedia/0c47a179-b7e1-486a-ab8a-84c439eca9fe/Brozura-MMR verze_4-2-stare-grafiky-Delimitace-a-NSu-final.pdf.aspx?ext=.pdf [zdroj ke dni 24. 2. 2020]

5) https://www.mmr.cz/getmedia/5e53b6c2-079a-4942-b3b6-cedf944b601f/ Brozura-Rekodifikace-stavebniho-prava-Verze-Meziresortni-pripominkoverizeni.pdf.aspx?ext=.pdf [zdroj ke dni 13. 1. 2020]
} 
na vydávání rozhodnutí. V řadě př́padů by mělo dojít $\mathrm{k}$ určitému rozštěpení působnosti dotčených orgánů. Tato schizofrenie je velmi kritizována odbornou veřejností. ${ }^{6}$ Lze přisvědčit, že takovéto navrhované řešení je přinejmenším sporné a dle názoru autorky neposkytuje dostatečný právní základ pro změnu v organizaci veřejné správy v navrhovaném rozsahu. ${ }^{7)}$ Jako další námitka proti navrhovanému řešení se nabízí i stávající praxe, kdy současný dlouholetý princip organizace veřejné správy, tedy členění pravomocí orgánů dle rezortů vychází mimo jiné z rezortního organizačního principu. Tento princip zajišt'uje vždy v dané oblasti výkonu veřejné správy jednotný výkon s jedním ústředním orgánem veřejné správy včetně ochrany veřejných zájmů v rámci daného rezortu.

Další změnou v organizaci veřejné správy by pak mělo být sloučení speciálních stavebních úřadů s obecnými ( 88 a násl. navrhovaného stavebního zákona), a to i přes skutečnost, že oddělení obecných a speciálních stavebních úřadů je založeno již historicky $\mathrm{z}$ důvodů technické specifičnosti staveb, jež jsou speciálními stavebními úřady povolovány (např. povolování staveb vodních děl se od 19. století vyvíjelo po samostatné linii (zákon č. 93/1869 (ř́šský vodní zákon), pro České země zákon č. 71/1870 - vodní zákon, pro Slezsko zákon č. 65/1870, zákon č. 51/1870, o používání vod a ochraně před nimi.), včetně toho, že povolování staveb speciálními stavebními úřady úzce souvisí i s jinými činnostmi na daném úseku, např. u staveb vodních děl se jedná o povolování nakládání s vodami.

\subsection{Automatické povolení (§ 106)}

Návrh zavádí mimo jiné institut tzv. automatického povolení, kterým se svým způsobem převádí celý proces stavebního řízení do režimu ohlašování.

6) Např. Otevřený dopis proti věcnému záměru nového stavebního zákona 101 akademiků ze dne 16. 4. 2019, zdroj: https://www.scribd.com/ document/407686487/Otevr-eny-dopis-StavZ-16-4-19\#from_embed (ke dni 19. 6. 2019).

7) KLIKOVÁ, Alena. Dotčené orgány a ochrana veřejných zájmů ve stavebním právu a jejich vliv na délku řízení vedených dle stavebního zákona. Stavební právo: bulletin, Praha: Česká společnost pro stavební právo, 2019, roč. 2019, č. 2, s. 36-41. ISSN 1211-6386.
„(1) Pokud stavební úrad nerozhodne do 60 dnů od zahájení řizeni nebo ve lhůtě prodloužené podle $\$ 102$ odst. 2, dojde v první den po uplynutí této lhůty k automatickému povolení záméru. “

Kritiky bývá tento návrh označován za velmi sporný, nebot’ je otázkou, zda taková úprava bude mít deklarovaný dopad, tedy urychlení povolovacího řízení. Prvním důvodem je obava, že stavební úruady z nedostatku času, budou žádosti rozhodovat negativně, nebot' nebudou schopny např. ve velkých věcech řádně vše posoudit a projednat. Na stanu druhou zde vzniká riziko, že tímto způsobem bude naopak ,povolena“ stavba, u níž je povolení zcela nežádoucí.

\section{ZÁVĚR}

Jak je z výše uvedeného patrné, současný stav rekodifikace veřejného stavebního práva je ve fázi projednávání paragrafovaného znění stavebního zákona. Vzhledem k rozsáhlosti řešené problematiky a k množství kritických připomínek, je možné, že cesta $\mathrm{k}$ vyřešení všech problémů bude ještě dlouhá. Navrhovaná účinnost stavebního zákona by měla být k 1. 1. 2022. Je však otázka, zda je tento termín reálný, nebot' v době dvou let by mělo dojít k rozsáhlé digitalizaci a k zajištění reorganizace veřejné správy spočívající v oddělení stavebních úřadů a části dotčených orgánů.

Jednoznačně lze souhlasit se základní ideou návrhu zákona, tedy urychlením a zjednodušením stavebních řízení, je však otázkou, zda navrhovanými změnami je možné tohoto cíle dosáhnout.

\section{LITERATURA}

[1] Stavební zákon č. 183/2006 Sb., ve znění pozdějších předpisů.

[2] Návrh rekodifikace veřejného stavebního práva.

[3] Návrh nového stavebního zákona.

[4] KLIKOVÁ, A. Aktuální stav rekodifikace veřejného stavebního práva. Sbornik přispěvků konference Expert Forensic Science Brno 2020. VUT v Brně, Ústav soudního inženýrství, Brno, 2020, s. 284-288, ISBN 978-80-214-5829-1.

\section{Správná citace:}

KLIKOVÁ, A. Aktuální stav rekodifikace veřejného stavebního práva. Soudní inženýrství, 2020, 31(1), $22-24$.

DOI: http://dx.doi.org./10.13164/SI.2020.1.22. ISSN 1211-443X. 